\title{
"[S]OMETIMES AMERICA NEEDS TO BE PUSHED": Amy Waldman's The SUbmission and THE EARLY American 9/11 Novels
}

\begin{abstract}
By comparing Amy Waldman's novel, The Submission (2011), to the earlier, already canonized American 9/11 novels, such as Don DeLillo's Falling Man (2007), John Updike's Terrorist (2006), and Jonathan Safran Foer's Extremely Loud and Incredibly Close (2005), this article suggests that Waldman's novel turns many tropes, themes, and customs of the earlier novels upside down, and thus, epitomizes a new phase in 9/11 literature. The article focuses on how The Submission redirects the reader's sympathies, undoes the atmosphere of suspicion and paranoia, drops the $9 / 11$ victims and the attacks themselves from their pedestal, and deconstructs stereotypes. It shows how Waldman's novel steps away from the trauma and the victimhood of the earlier novels and takes a critical focus on the consequences of the attacks. Additionally, the article suggests that The Submission comments on and criticizes the dominant 9/11 discourse, while the earlier American 9/11 novels, perhaps unwittingly, tend to support it.
\end{abstract}

\section{Keywords}

Contemporary American literature; 9/11 novel; Amy Waldman; The Submission; 9/11 discourse

After the 9/11 attacks, questions of what had happened and why began forming quickly. As Adam Hodges and Chad Nilep describe it, there was "a cry for meaning to be made out the devastation" (2007: 2). President Bush answered this cry by posing a question "Why do they hate us?" and responding it with a simplified answer: "They hate our freedoms - our freedom of religion, our freedom of speech, our freedom to vote and assemble and disagree with each other." (2001) 
Such statements framed the discourse about 9/11 in a way which disregarded all political, historical, and economic context of the attacks and presented them as a value-based battle between good and evil. Instead of concentrating on the reasons behind the attacks or their consequences, the focus in the media and politics was on the trauma suffered, which, as Sonia Baelo-Allué states, lent its support to the ideas of American innocence, exceptionalism, and patriotism (2016: 167). As Ann E. Kaplan puts it, "national ideology was hard at work shaping how the traumatic event was to be perceived" (2005: 13). Nevertheless, as a few years went by, artistic and cultural representations, such as 9/11 novels, started joining in on shaping the perception of the 9/11 attacks. Even though there is no consensus about the definition, terminology, or extent of the subgenre of $9 / 11$ novels ${ }^{1}$, it is agreed that in the past 15 years, dozens of novels that can be categorized as such have been published. The most popular of these novels form a group that can be even described as a $9 / 11$ canon $^{2}$. Some of the most well-known examples of this canon are Don DeLillo's Falling Man, John Updike's Terrorist, and Jonathan Safran Foer's Extremely Loud and Incredibly Close, which are analyzed in this article.

While the post-9/11 media and politics tended to rely in their discourse on strong oppositions of good and evil, patriotism, and sacralization, 9/11 novels were expected to offer a more complex view of what had happened. As Arin Keeble states, literature was hoped to "provide answers and give meaning to a newly uncertain world" and provide a kind of a counternarrative to the dominant discourse (2014: 6-8). Some researchers, Keeble included (2014: 8), suggest that this is indeed what happened. Martin Randall states that while the dominant 9/11 discourse has affected $9 / 11$ novels, they approach the topic in a more multifaceted manner than the discourse (2011: 16-18). Also Véronique Bragard, Christophe Dony, and Warren Rosenberg propose that after the initial shock, many writers have indeed presented "counter-narratives" to the official 9/11 discourse (2011: $3)$.

Yet, the majority of the early American 9/11 novels retreated to a similar world of trauma and depoliticization as the dominant 9/11 discourse: alongside DeLillo's, Updike's, and Foer's works, many popular 9/11 novels from the 2000s, such as Claire Messud's The Emperor's Children (2006) and Jay McInerney's The Good Life (2006), revolved around the private lives of white, upper-middleclass Americans who have been traumatized by the $9 / 11$ attacks. The domesticated, depoliticized tendencies of these novels started to draw some criticism from scholars and literary critics, such as Richard Gray $(2011$ : 16-17,30) and Pankaj Mishra (2007), who have been calling for novels that would approach the attacks in a more global, public, and political way. Yet, as Sonia Baelo-Allué notes, the trauma-focused novels have kept their position at the top of the scholarly canon (2016: 168).

The most recent literary responses to $9 / 11$ have, however, started to form the long-awaited counternarrative to the 9/11 discourse, which most notably can be found in Amy Waldman's 2011 novel The Submission, as is also noted by Keeble 
(2014: 191-192). The Submission is set in the year 2003 in New York where an American Muslim Mohammed "Mo" Khan wins the competition for designing the 9/11 memorial. The result brings about a severe public uproar and a vast media storm that revolve around Mo and his design, or more specifically, the fact that he is a Muslim. Waldman's novel has been considered to represent a new wave of 9/11 novels as it focuses less on private trauma than on politics and societal consequences. Baelo-Allué sees The Submission as a cultural trauma novel in comparison to the earlier, psychic trauma novels (2016: 165-172). In Keeble's opinion, what mainly separates Waldman's novel from the others is that it captures the "post-9/11 conflictedness" and is "directly political" in a way that other 9/11 novels are not (2014: 165-166). Nevertheless, there are many more ways in which Waldman's novel opposes and comments on the early, popular American 9/11 novels, and also the dominant 9/11 discourse. By comparing The Submission to DeLillo's, Foer's and Updike's novels, this article takes a specific look at how Waldman's novel reforms the tropes, themes, and patterns of the early, canonized 9/11 novels by redirecting the reader's sympathy to new directions, criticizing the atmosphere of doubt and paranoia, dropping the 9/11 attacks, their victims, and the victims' families from their sacred pedestal, introducing a more diverse set of characters, deconstructing stereotypes, and offering more complex identities. The article demonstrates that while Waldman's novel creates a real antithesis to the early $9 / 11$ discourse, the early novels in many respects repeat its simplified oppositions, ${ }^{3}$ stereotypes, and sacralization, and thus, end up reinforcing it instead. ${ }^{4}$

\section{Redirecting the reader's sympathy}

As mentioned, most of the popular American 9/11 novels from the 2000s revolve around people who have been traumatized by the attacks, and Foer's and DeLillo's novels are no exception. In DeLillo's Falling Man, these people are the Neudecker family: a 9/11 survivor Keith, his wife Lianne, and their son Justin. Their trauma ${ }^{5}$ is highlighted in different ways throughout the novel. Keith's traumatic experience causes him to become detached from life and reality: he lives in a state of haunted daze where regular meanings of things have disappeared, and his sense of self, time, and the outside world is broken. Lianne's trauma presents itself in her constant feelings of worry, fear, and anger. Both Lianne and Keith have trouble sleeping, develop strange obsessions, and their thoughts and behavior become more irrational as the narrative progresses. Their son also exhibits changes in his conduct: he spends his time searching the skies with binoculars for planes. In Foer's novel, the traumatized protagonist is a 9-year-old boy, Oskar Schell, who has lost his father in the 9/11 attacks. Like Keith and Lianne in Falling Man, Oskar also cannot sleep, and he too develops different obsessions and fears that are connected to the $9 / 11$ attacks.

Both of these novels are imbued with trauma: in addition to the characters' experiences, the trauma is present in the novels' form, style, and narrative techniques ${ }^{6}$. 
Virtually everything about these works is inviting the reader to feel intense sympathy towards the characters, and by extension, all Americans traumatized by 9/11. According to Howard Sklar, one of the key ingredients in creating narrative sympathy is the reader's judgment that the character's suffering is undeserved (2013: 53). In Foer's and DeLillo's novels this is accomplished by portraying the characters' trauma, the 9/11 attacks, without any kind of political, economic, or historical context and by depicting the characters as simply good and thus, undeserving. In Foer's novel, this is done by creating a protagonist who is a sweet 9-year-old child. Even though more complex, DeLillo's characters are still morally good as their flaws are generally portrayed to be a result of the trauma.

The Submission, however, turns the reader's sympathy away from the traumatized victims towards new targets as it takes on the topic of discrimination against Muslims in the post-9/11 United States. The narrative follows the memorial battle from several different viewpoints and thus offers, as Keeble describes it, "a real panorama of the American society" (2014: 171). There is Mo, a successful architect and a secular Muslim of Indian descent, and Claire Burwell, a wealthy 9/11 widow and a representative of the victims' families in the memorial jury, who sets out to support Mo. Another 9/11 widow, Asma Anwar, an undocumented immigrant from Bangladesh, decides also to side with Mo, while Sean Gallagher, an unemployed, anti-Islamic conservative who has lost his brother in the 9/11 attacks, starts to organize protests to stop the memorial.

The conversation about Islam and Muslims begins immediately when the jury finds out that the person behind the chosen design, the Garden, is a man named Mohammed. The Governor's representative Bob Wilner's reaction is a less than composed, "Jesus fucking Christ! It's a goddamn Muslim!". Other judges follow him wondering, "Is he even American?", or is he "one of the problematic ones", and even allude to the possibility of Mo being a terrorist (Waldman 2012: 19-21). The wildly absurd accusations and crude language guide the reader to side with the discriminated architect rather than the Islamophobic judges. This is further ensured with the structure of the narrative as the following scene introduces to us the infamous architect who turns out to be not so dangerous after all.

We meet Mo in a flashback scene where he is returning to New York from Los Angeles a week after the 9/11 attacks. While trying to board the plane, he gets pulled over for an interrogation. At the beginning of the interrogation, he thinks back to how already in just a week the attacks have affected his life. Mo had started to behave more docile just because he had been afraid how the terrorist attacks would influence people's opinion of Muslims. The judges' unfounded offensive reaction and Mo's fear of a reaction just like it gets the reader on Mo's side even before the interrogation begins.

During the interrogation, the questions presented underline that Mo is under suspicion just because of his assumed religion:

'Do you love this country, Mohammad?'

'As much as you do.' [...] 
'What are your thoughts on jihad?'

'I don't have any.'

[...] Do you believe you'd go to your heaven if you blew yourself up?'

'I would never blow myself up.' (Waldman 2012: 31)

Mo's answers emphasize the insanity of the questions and guide the reader to consider the whole interrogation as futile and insulting. This is furthermore highlighted with having Mo recap in his mind how he has actually always been a good, law-abiding citizen. When Mo returns home, he realizes that his suitcase is a mess because the agents have gone through it. Nevertheless, his anger over the whole episode disappears quickly when he sees the state his city is in: "[...] his bitterness was overwhelmed by the magnitude of mourning around him" (Waldman 2012: 35). Showing that Mo's sympathy is stronger than his anger ensures that the reader sees Mo as a good, caring person who is undeserving of the bad treatment he has received and thus worthy of the reader's sympathy. This sympathy is not only directed towards Mo because, as Keeble notes, Waldman's characters are strongly representative (2014: 181). As a result of this feature, the reader's sympathy extends towards the actual Muslims who have been discriminated against in the United States after 9/11.

This topic is also mentioned in DeLillo's Falling Man; however, the novel takes a very different approach to it. As mentioned, Lianne's trauma presents itself, among other things, as irrational thoughts and behavior. She, for example, keeps having strange, prejudiced thoughts about her Creek neighbor Elena: "They're the ones who think alike, talk alike, eat the same food at the same time. She knew this wasn't true. Say the same prayers, word for word, in the same prayer stance, day and night, following the arc of sun and moon" (DeLillo 2008: 86-87). What is interesting is that Lianne seems to acknowledge the illogicality of her prejudiced thoughts. The same pattern is repeated when Lianne goes to Elena to complain about the "Islamic music" Elena keeps playing. Lianne is rude and hostile towards Elena because she feels the music is insulting at a "sensitive time" like this, and at the end of the scene she ends up punching her in the face. As Lianne is leaving, she realizes again the complete irrationality of her actions: "Lianne knew she was going crazy even as she turned and walked out" (DeLillo 2008: 151).

When considering what these scenes are trying to convey to the reader, we have to take into account the fact that Lianne is otherwise portrayed in the novel as a morally good person: she is a caring mother and she volunteers to help Alzheimer patients. Thus, her behavior towards Elena seems out of character. This interpretation is supported by the fact that Lianne is being contradictory: she understands the problem with her prejudice, yet she does not change her behavior. This is emphasized moreover when she tells Keith what has happened:

It was totally crazy. I could hear myself speaking. My voice was like it was coming from somebody else.' [...] 'I need to get more sleep. That's what 
I need,' [...] 'I wake up at some point every night. Mind running nonstop. Can't stop it.' [...] 'Thoughts I can't identify, thoughts I can't claim as mine.' (DeLillo 2008: 156-157)

Lianne is in a sense separated from her actions by proving that she does not recognize her own thoughts or behavior. Instead, her ethically questionable thoughts and behavior are portrayed to be the result of the 9/11 trauma. Thus, the reader is invited to feel sympathy towards Lianne rather than to judge her. Like Sven Cvek states, Lianne's reaction to the "Islamic music" is depicted as an inevitable, uncontrollable "reflex" so she cannot be held accountable for her actions (2011: 202-203). While DeLillo's novel acknowledges the existence of the unfounded prejudice against Islam and Muslims after 9/11, it seems to suggest that it is an understandable reaction to the trauma suffered. It also implies that this reaction will pass with time as Lianne's attitude towards Islam is already more accepting three years later. In reality, the heightened animosity in the aftermath of the attacks was just the beginning: attitudes towards Islam and Muslims have actually worsened in the past years. ${ }^{7}$ Yet, most of the early canonized 9/11 novels completely disregard the whole matter, like Foer's novel does, while others seem to make the problem worse, like Terrorist and Falling Man do.

\section{Undoing suspicion and doubt}

John Updike's Terrorist plays strongly with the heightened sense of suspicion and paranoia of the years following the 9/11 attacks. It tells the story of Ahmad Asmawy Mulloy, an 18-year-old, pious Muslim, who, guided by his radicalized imam Shaikh Rashid, ends up participating in a terrorist plot. The whole narrative is built in a way which invites the reader to have suspicions about all the Muslim characters in the novel and then proves these suspicions to be correct. Terrorist, similarly to DeLillo's Falling Man ${ }^{8}$, emphasizes that there is evil walking among us, ready to strike if we do not keep our eyes open. Thus, they both offer some unwitting support to Homeland Security's "See something, say something" campaign and to the discrimination and prejudice directed at Muslims and Arabs in the post-9/11 time. ${ }^{9}$

The Submission takes a different approach to this topic. In the beginning of the novel, Claire, a liberal 9/11 widow, sets out to support Mo but quickly begins to question his motives for designing the memorial and later, the meaning of his design, the Garden. This movement from trust to doubt begins when Claire meets Mo the first time in an event held to announce his victory. During their encounter, Mo notices that Claire is expecting him to thank her for her support. Yet, Mo does not want to do so as he has been growing more stubborn and defiant because of the discrimination he has faced since his victory. He thinks that thanking her "would suggest, somehow, that she was doing something extraordinary. He wouldn't congratulate her for being decent. Her expectation made him want 
to refuse" (Waldman 2012: 42). By having the scene focalized through Mo and by explaining the reasons for his defiance, his disinterest in thanking Claire is portrayed as understandable.

Claire, however, does not understand this and is hurt. This contributes to her suspicions, and she begins to give new meanings to things she otherwise might not have even noticed. When she looks at a photo of Mo and the judges taken at the event, she notices that there are 13 gloomy faces and Mo alone is smiling. This bothers Claire: "Khan's grin nettled her, suggesting deafness to the rancor and grief around him. It made her wonder if he saw the memorial as anything but a career milestone" (Waldman 2012: 147). The reader is guided to consider Claire's irritation and doubt as unfounded because throughout the novel it is made clear in Mo's focalizations that there is no reason to doubt him.

Mo's smile should not of course cause any kind of suspicion to begin with. Yet, it is further made sure that the reader understands why Mo is smiling by showing the scene from his point of view: "'Smile,' the photographer called out. From reflex Mo did" (Waldman 2012: 144). In addition, the reader knows that Mo is not by any means oblivious of the sorrow and anger around him: on the contrary, he has expressed sympathy for the $9 / 11$ victims and their families and is very aware of the rancor he has caused as he is indeed, in the middle of it.

It is not until the New York Times points out the Islamic influences of the Garden that all the hell breaks loose. The media swiftly begins to brand Mo's Garden as a "martyr's paradise", he starts to receive threats, and protesters and media begin patrolling outside his apartment (Waldman 2012: 149). Claire's suspicions deepen too as she meets with an amoral scoop-hunting journalist Alyssa Spiers, who feeds her false information that Mo would have made a threat against the American embassy when visiting Kabul. After the conversation, Claire cannot let go of her doubts anymore, and she starts retracting her support for Mo's design.

The situation evolves to an impasse, where Claire wants Mo to reassure her that there is nothing ominous behind his design, but he refuses to answer because the only reason everyone is asking these questions and making accusations is his religion. Close to the end of the novel, Claire and Mo sit down once more to try to resolve the situation, but they keep going in circles. Claire asks if the Garden is a martyr's paradise and Mo still refuses to answer. When Claire tries to explain to Mo that it is not about him but his religion, Mo has had enough and says:

How would you feel if I justified what happened to your husband by saying it wasn't about him but about his nationality - his country's policiesdamn shame he got caught up in it, that's all — but you know, he got what he deserved because he paid taxes to the American government. I get what I deserve because I happen to share a religion with a few crazies? (Waldman 2012: 348)

In his comment, Mo brings up the problem of generalization by saying that equating him with the terrorists just because they share a religion is as absurd as saying 
the 9/11 victims bore responsibility for their fate because of their government's actions. Claire, however, hears it in a different way:

Claire went taut. 'Damn shame.' 'What he deserved.' The words seemed to strike the fragile bones of her ear, even as she wasn't exactly sure what he had said: she had been thinking and listening at the same time, which made it hard to hear. But this, at last, had to be what he really thought. It pained her, sickened her, to think that perhaps vile Alyssa Spier was right, that Khan did see $\mathrm{Cal}$ as mere collateral damage in a war America had brought on itself, that he believed $\mathrm{Cal}$, generous, good-natured $\mathrm{Cal}$, bore responsibility, guilt, simply because he was American. (Waldman 2012: 348)

The mention of her husband upsets Claire so deeply that she does not care anymore what Mo is actually saying. The fact that Mo drops the $9 / 11$ victims from the pedestal where they have been put, and where Claire clearly puts her husband, drives her into a blind rage. The scene reflects the conversation that has been developing throughout the novel where the families of the 9/11 victims, and the public in general, refuse to listen to rational arguments because they feel these arguments are insulting the sacred memory of the victims and the 9/11 attacks themselves. Considering the representative nature of the novel, the scene can be seen to refer to the actual sacralizing $9 / 11$ discourse - a topic which will be further analyzed in the next section of the article.

Claire's comment guides the reader to once again notice the illogicality of her suspicions as she feels that without listening to what Mo is saying, she can finally deduce what he has been thinking all along: she is ready to believe only the information that would confirm her suspicions. Interestingly, Tim Gauthier sees that the reader would actually share Claire's suspicions. According to him, the novel intends to keep the reader in a similar state of unconsciousness that Claire is in and, thus, have them wondering if Mo's silence is truly caused by his principles or rather by some "hidden motives" (Gauthier 2015: 209). Nevertheless, the reader has been proven time and time again throughout the novel that Mo is, in fact, a decent, sympathetic guy without any kind of grudge towards the United States or Americans. It is true that the reader is not explicitly told what the Garden means to Mo, but this should not create any kind of suspicion as nothing in Mo's words or behavior guides neither Claire nor the reader towards a conclusion that the Garden would be a "martyr's paradise".

Yet, the novel does offer one more dimension to the mystery that is Mo's design. In the chapter preceding the epilogue, the novel returns to Mo's trip to Kabul. The chapter offers new information about this trip and reveals that Mo indeed did see a garden in Kabul, which does have similar features to his winning design. Gauthier concludes that this revelation and the fact that Mo has not mentioned it raises suspicions about the real meaning of this influence (2015: 210-211). Yet, Mo has, in fact, mentioned publicly that one of the influences of the design is Islamic gardens (Waldman 2012: 278-279). Thus, the fact that Mo has seen 
a garden in Kabul should not cause any kind of suspicion about his design. Considering what kind of a commotion Mo's religion has created, it is quite understandable that he does not want to advertise seeing a garden in Kabul. Also, as Baelo-Allué, notes, Mo finds peace in the garden in Kabul, so if the scene does reveal something about the "secret motives" of Mo, it is that he has tried to convey a feeling of peace with his design (2016: 178).

Nevertheless, Gauthier is correct in saying that the description of Mo coming across the garden in Kabul is left at the end of the novel to be a kind of a revelation. Also, it is true that Mo's thoughts about the meaning of his design are indeed intentionally left mainly untold. However, this is not done to make the reader doubt Mo as Claire does but instead to notice the illogicality of her doubts. It is a way of showing how prejudice can affect people's interpretations and, thus, mislead them.

\section{Unequal victims, unequal society}

While in DeLillo's novel the 9/11 trauma works as an explanation or even a justification for the characters' ethically questionable behavior, Waldman's novel criticizes using trauma and loss as an excuse to justify poor behavior or as means of getting what you want. In the beginning of the novel, when the judges are trying to decide on the winning design, Claire tries to persuade the rest of the memorial jury onto her side by reminding them of her dead husband. She is then "taking some satisfaction in the downcast eyes and guilty looks along the table. They'd all lost, of course [...] [b]ut only she had lost her husband. She wasn't above reminding them of that tonight" (Waldman 2012: 4).

The privileged position of the victims' families is criticized more clearly later on in a hearing where the public, the victims' families, and experts gather to voice their opinion about Mo's design. When Mo is giving his speech, people in the audience start booing and yelling offensive slogans, such as "Save America from Islam!" and "No Muslim memorial!". The head of the jury, Paul Rubin, steps in and says that if the public does not start behaving they will not be heard. The audience reacts to this by yelling: "“We're not the public, we're the families,' [...] 'You can't say we don't count.' Righteous applause rippled" (Waldman 2012: 279). The self-importance of the victims' families is embedded in the line "You can't say we don't count" and in the narrator's word choice "righteous". The word is used to criticism the sanctimonious smugness of the families, and it is guiding the reader to judge the people who are trying to justify their Islamophobic views with their victimhood. The Submission thus creates a clear opposition to DeLillo's novel, which is asking the reader to understand the characters' ethically questionable views and behavior because of the trauma they have suffered.

This criticism is repeated closer to the end of the novel when Claire and the judges are trying to come to an understanding about Mo's design. Claire has changed her position and is now making a case against Mo while the other judges 
are finally ready to support him. Claire tries to appeal to them by saying that the rest of the victims' families are against Mo's design too. She asks, what is she supposed to tell them. One of the judges, Maria, answers:

'Tell them to get over it,' Maria said. Her crudeness shocked Claire. [...] 'To be blunt, I'm tired of hearing about the families. You wouldn't know from the way we're talking that an entire nation was devastated by this attack.' Nervous half-smiles eeled across jurors' faces. The words had broken some taboo, robbed Claire of some talismanic enrobement. (Waldman 2012: 305)

The talk about "breaking a taboo" and taking away some "talismanic enrobment" can be seen to refer to the unfairly privileged position that the victims' families have gotten in society, but it can also be seen to reflect the untouchable, sacred position of the 9/11 attacks in the dominant discourse. David Simpson, for example, talks about "rhetorical colonization" which constructed the Ground Zero as a "sacred ground" and the victims as "heroes" (2008: 213-214). Similarly, Randall states in his work that the dominant discourse has sacralized the 9/11 attacks and mentions that this discourse has affected 9/11 literature (2011: 16-18). This effect is the most evident in Foer's novel, which David Holloway describes as "exaggeratedly "narcissistic" and verging "on melodrama at times" (2008: $114,116)$. By having sweet, traumatized 9-year-old Oskar narrate the story, it is ensured that the reader will see the 9/11 attacks only in a depoliticized and sentimental way. Additionally, the novel depicts the $9 / 11$ victims in a sacralizing light as it shows Oskar's father, who perished in the attacks, through the eyes of his adoring son who is trying in different ways throughout the novel to feel closer to, and in a sense, commemorate, his father. Like Holloway says, the novel pulls the reader "into the private agonies of the traumatized self and away from any meaningful contextualizing of 9/11 in public or historical space" (2008: 114). ${ }^{10}$ Waldman's work, however, refuses to succumb to this way of representing the 9/11 attacks, its victims and their families.

The Submission clearly recognizes the problems of the dominant 9/11 discourse and their repetition in 9/11 novels and aims to change them. It does so also by diversifying the representation of the traumatized Americans and the 9/11 victims. The way these people are represented in the popular American 9/11 novels from the 2000 s, one would think that $9 / 11$ was a tragedy only concerning white, upper-middle-class Americans. ${ }^{11}$ Waldman's novel, however, brings forth people from different backgrounds. Mo, for example, is of Indian descent, Sean of Irish origin, and Asma is from Bangladesh. Sean and Asma are also far from upper middle class as they are both poor and uneducated.

The Submission uses characters from various backgrounds to raise the issue of inequality among the 9/11 victims. This is done especially with Asma's character, whose husband, a cleaner in the World Trade Center, has been killed in the attacks. She opens her first section by thinking, "How could you be dead if you did not exist?" (Waldman 2012: 88) With this question, Asma is wondering how it is 
possible that her husband is not, as an undocumented immigrant, acknowledged as a $9 / 11$ victim. One day, she sees on television how a popular right-wing talk show host comments on the topic:

'[...] The illegal immigrants who died came here seeking opportunity, but if they had stayed home they would still be alive. Isn't that the greatest opportunity of all?' Asma ground her fists into the sofa cushions, furious that there was no one to speak for her husband, for the army of workers who cleaned and cooked and bowed and scraped and when the day came died as if it were just another way to please. (Waldman 2012: 97)

The host's heartless comment and people's efforts to wipe Asma's husband from history justify her emotional reaction. Asma's thoughts do not only bring up criticism towards the treatment of immigrants but also imply that the working-class people have been considered as less important victims. This notion once again reflects the realities of the aftermath of the attacks. The undocumented workers of the twin towers were indeed not recognized as victims and the social class of the victims seemed to determine their importance (Gauthier 2015: 192-193, 214).

In the speech that Asma gives in the hearing about the memorial, she says out loud what she was thinking earlier: "Does my husband matter less than all of your relatives?" (Waldman 2012: 296). She thus voices the question that has been in the air throughout the novel: are all 9/11 victims equally important? The question is not limited to only $9 / 11$ victims; it rather raises an issue of the inequality of American society in general. This theme is construed in the novel with several different characters: Sean, an uneducated, young man, cannot get his voice heard as the older, wealthier, and more educated people, such as Claire and Paul, look down on him. Sean thus tries to get the upper hand on Claire by using his position as a man against her by trying to kiss her "just to prove he could" (Waldman 2012: 110). Similar behavior is repeated virtually by all the male characters in the novel as they assess Claire by her looks only and try constantly to tell her what to do. Mo's social standing, even though he is an educated, wealthy man, is undermined by his ethnic and religious background. Asma, however, gets dealt the worst hand, since in addition to her religious and ethnic background, she is a poor, uneducated woman. In the end, the only character whose voice and position in society is not questioned is the head of the jury, Paul Rubin's, who is a very wealthy old white man. This is how The Submission demonstrates how the aspects of ethnicity, religion, educational background, age, and gender affect people's social standing. This theme is intertwined in the novel with the idea of the complexity of identity. Waldman's novel shows how a person is judged in a society based on different aspects, how mistaken these judgments often are, and how a person's identity will always be more than a sum of these characteristics. The novel's approach to identity and stereotypes will become more clear in the next section of the article. 


\section{Deconstructing stereotypes}

In many of the canonized $9 / 11$ novels, the characters' identities tend to be determined by one singular feature. For DeLillo's Keith and Lianne and Foer's Oskar, it is the trauma they have suffered, and they are identified simply as victims. This simplified characterization is even more evident in Updike's Terrorist as the majority of the novel's characters are embodiments of different, often offensive, stereotypes. The Muslim characters in the novel are all terrorists who hate the United States. The city of New Prospect, where the novel is situated, is inhabited by immigrants and depicted as a dangerous place filled with graffiti and gangs. Tylenol Jones, the only African American male character in the novel, is portrayed as a simple-minded, violent pimp, and his African American girlfriend, Joryleen Grant, is a beaten prostitute who simply submits to her fate. The novel's Jewish character, Jack Levy, is depressed, cynical and Islamophobic. The IrishAmerican character, Terry Mulloy, is a flimsy, red-haired, freckled working-class woman.

Significantly, Updike's characters do not evolve outside of these stereotypes in the novel. If we take a look at characters in The Submission, we can see that while they also resemble familiar stereotypes, the characters challenge these stereotypes as the narrative progresses, as is also noted by Baelo-Allue (2016: 173174). Like Keeble (2014: 171-172) and Baelo-Allué (2016: 173) have observed, Asma, for example, starts out in the novel as an oppressed Muslim woman. She tells us how "[s] he had resolved to be as brave [as her father], only to learn that as a woman she wasn't expected to be." (Waldman 2012: 127) As Dohra Ahmad states, the oppressed Muslim woman is a common stereotype in contemporary American popular literature (2009: 105). Peter Morey and Amina Yaqin point out that this trope also has been proliferating in the post-9/11 period in the media, entertainment, and politics (2011: 2-3, 10). As the events unfold, Asma, however, steps outside this stereotype by finding her independence and voice by standing up in the memorial hearing and speaking her mind, as is also noted by Keeble (2014: 172). Nevertheless, Asma finds her freedom in the "West", and this pattern is, according to Ahmad, actually a part of the oppressed Muslim woman stereotype. Ahmad points out that in popular literature, the oppressed woman is always "in need of rescue from an enlightened West" (2009: 106). Yet, in Waldman's novel, the pattern is not that simple. While Asma does find her voice in the United States, she uses it to express her disappointment to the country. In her speech at the memorial hearing, she tells the American public what she thinks of the discrimination and animosity towards Muslims and immigrants in the country she had thought to be a liberal, tolerant utopia by saying: "You should be ashamed!" (Waldman 2012: 297).

Similarly, Mo's character reflects many common stereotypes about Muslims. In the beginning of the novel, he is the "innocent victim" while other people see him as a "dangerous fanatic", both of which Morey and Yaqin mention to be popular Muslim stereotypes (2011: 143). However, Mo turns out to be neither of 
these. He does not just roll over and accept the role of a victim when he comes across discrimination but instead starts to fight. People's suspicions of Mo as being somehow dangerous are proved wrong and thus also this stereotype is shown to be defective.

Sean and Claire start out in the novel as two opposing extremes in every possible way: Claire is a rich, educated, composed, elegant liberal, while Sean is a poor, uneducated, impulsive, crude conservative. Yet, as the narrative progresses, they both move from these positions almost to the opposite ends of the spectrum. Claire slowly begins to doubt Mo's garden and realizes that her liberal values are not actually her own but rather her husband's. Sean is strongly anti-Muslim in the beginning of the novel, but it quickly becomes clear that he is only following the example of his Islamophobic family in order to be accepted by them. By the end of the novel, Claire has moved to oppose the memorial she spent the whole novel defending and Sean has decided to stop fighting the memorial he has spent the whole novel opposing. By showing the immense change in the characters, the novel proves that identities are not fixed but fluid. The Submission also opposes the pigeonholes of good and evil, which Foer's, DeLillo's, and Updike's characters can be easily categorized into, by showing how all of the characters move in a gray area of morality. By doing so, Waldman's novel, again, does not reform only the patterns of the early $9 / 11$ novels but also of the simplified, opposition-filled 9/11 discourse..$^{12}$

It seems as if Waldman has created these stereotypes only to deconstruct them and thus show that people cannot be categorized by a single feature. The novel demonstrates the mistakes people make when trying to categorize each other, and it hence supports the view that identities cannot be determined from the outside. The Submission aims to convey that things in themselves do not have a meaning before we ascribe them one: without preconceptions, a Muslim is just a Muslim and a garden is really just a garden.

The article has demonstrated how The Submission truly does represent a new phase in the subgenre of 9/11 novels. It reforms the patterns of the earlier, popular 9/11 novels and the 9/11 discourse: the early, canonized 9/11 novels and the dominant discourse have been inclined towards a simplified, respectful and traumafocused representations, while The Submission has taken a clear step away from this restrictive custom. Considering that Waldman's novel has been generally met with positive reviews (Keeble 2014: 165; Baelo-Allué 2016: 170), it would seem that a more diverse and critical representation of the attacks has become more acceptable in the 2010s. Thus, The Submission does not reflect only a change in the representation of the 9/11 attacks but also a change in how this representation is received; a change in values and attitudes that might make the 2010s a decade of rewriting $9 / 11$. 


\section{Notes}

1 Or post-9/11 novels; the scholarship tends to use these terms synonymously.

$29 / 11$ canon refers here primarily to the critical, that is, the scholarly, canon. The existence of a canon in such a young subgenre is, of course, debatable, but the recent scholarship has commonly accepted the existence of a (post) 9/11 canon as a baseline. See, for example, Keeble (13-16) and Petrovic (ix-xvi).

3 Gray has also pointed out that some 9/11 novels, including Falling Man and Extremely Loud and Incredibly Close, offer a response that is similar to the reactions of some politicians and the mainstream media, especially in regard to relying on oppositions. He, however, does not see this to be specifically a characteristic of the early 9/11 novels (Gray 2011: 16-17, 65). When talking about the development of the 9/11 novel, it is worth mentioning that Petrovic has recently suggested that post-9/11 literature (including movies and television programs) in general have evolved in a way that the early works rely on the dominant discourse's ideas of victimhood and exceptionalism, while the latter works offer more pluralistic and critical views (Petrovic 2015: ix-xvii).

5 Even though the concept of trauma is used often in this section, the text does not focus on the different characteristics of a traumatic experience, but rather on how emphasizing trauma affects the reader's interpretation of the narrative. Like Michelle Balaev, I see literary trauma as a multifaceted concept which goes beyond the limited, traditional psychoanalytical definition. Trauma is not a fixed, indecipherable thing; instead, its meaning depends on the cultural and historical context (Balaev 2014: 1-8).

In both novels, the characters' thoughts and the plot jump from one thing to another without any introduction creating fragmented, nonlinear narratives which reflect the characters' trauma. For more on how these features relate to trauma, see, for example, Versluys (2009). In DeLillo's novel, the trauma is also highlighted by creating distance between the reader and the characters which emphasizes the characters' confused, traumatized mindset. In Foer's novel, the use of photographs and the "unconventional use of page-space and typography" in the narrative often intensifies, as Holloway notes, the reader's experience of the characters' trauma (2008: 115-116). In comparison, Waldman's novel is realistic in tone, it has a rather straightforward narrative and it includes several focalizers, and it thus differs from the early novels also in its form, narrative technique, and style.

7 In the beginning of the 2000 s, over 50 percent of Americans said Islam is not more likely to encourage violence than other religions, while only 25 percent said it is. In 2014,50 percent of people said Islam is more likely to encourage violence, while only 39 percent said it is not (PewResearchCenter 2014). Anti-Muslim assaults have risen in 2015 to the same peak they reached right after the 9/11 attacks (Kishi 2016).

$8 \quad$ Falling Man includes also a story of a fictional 9/11-hijacker Hammad - a character which lacks depth, and in many respects, relies on orientalist clichés, as is also noted by Sascha Pöhlman (2010: 59).

$9 \quad$ On discrimination and prejudice against Muslims and Arabs, see, for example, Haddad (38) and Peek $(1,95)$. On the Muslim-American experience of the post-9/11 time, see, for example, PewResearchCenter (2011).

10 Regarding the lack of meaningful contextualizing in Foer's novel, it is worth mentioning that the novel actually does include also several narrative strands which offer some historical connections: there is Oskar's grandparents' story, who both lost their families in the WWII bombing of Dresden. Also, a story of a Japanese woman who lost her daughter in the bombing of Hiroshima is included. Both these stories are, however, used only to draw a connection between the innocent victims of these historical events and the innocent victims of the 9/11 attacks. Like Versluys puts it, the novel "universalizes grief" (2009: 82).

11 The predominance of white, upper-middle-class characters is a widely accepted notion in the 9/11 scholarship: see, for example, Sykes $(249,256)$ and Knapp (2014). 
12 The oppositions in the 9/11 discourse are pointed out, for example, by Banita (29), Randall (6-7), Vanderwees (230-234), and Keeble (2014: 166-167), who also notes that The Submission opposes this discourse.

\section{References}

Ahmad, Dohra (2009) "Not yet Beyond the Veil: Muslim Woman in American Popular Literature." Social Text 27 (2): 105-131. Accessed on April 26, 2017.

Baelo-Allué, Sonia (2016) 'From the Traumatic to the Political: Cultural Trauma, 9/11 and Amy Waldman's The Submission.' Journal of the Spanish Association of Anglo-American Studies 38 (1): 165-183. Accessed on April 26, 2017.

Balaev, Michelle (2014) 'Literary Trauma Theory Reconsidered'. In: Balaev, Michelle (ed.) Contemporary Approaches in Literary Trauma Theory. Basingstoke: Palgrave Macmillan, 1-14.

Banita, Georgiana (2012) Plotting Justice: Narrative Ethics and Literary Culture after 9/11. Lincoln: Nebraska University Press.

Bragard, Veronique, Christophe Dony and Warren Rosenberg (2011) 'Introduction.' In: Bragard, Veronique, Christophe Dony and Warren Rosenberg (eds.) Portraying 9/1: Essays on Representations in Comics, Literature, Film and Theatre. Jefferson: McFarland, 1-9.

Bush, George W. (2001) 'Address to the Nation.' Presidential Rhetoric, September 20, http://www. presidentialrhetoric.com/speeches/09.20.01.html Accessed on July 28, 2017.

Cvek, Sven (2011) Towering Figures: Reading the 9/11 Archive. New York: Rodopi.

DeLillo, Don (2008) Falling Man (2007). Export Edition. New York: Scribner.

Foer, Jonathan Safran (2005) Extremely Loud and Incredibly Close. Boston \& New York: Houghton Mifflin.

Gauthier, Tim (2015) 9/11 Fiction, Empathy, and Otherness. Lanham: Lexington Books.

Gray, Richard (2011) After the Fall: American Literature Since 9/11. Chichester: Wiley-Blackwell.

Haddad, Yvonne Yazbeck (2011) Becoming American? The Forging of Arab and Muslim Identity in Pluralist America. Waco: Baylor University Press.

Hodges, Adam \& Chad Nilep (2007) 'Introduction: Discourse, War and Terrorism.' In: Hodges, Adam and Chad Nilep (eds.) Discourse, War and Terrorism. Amsterdam: John Benjamins, 1-17.

Holloway, David (2008) 9/11 and the War on Terror. Edinburgh: Edinburgh University Press.

Keeble, Arin (2014) The 9/11 Novel: Trauma, Politics and Identity. Jefferson: McFarland.

Kishi, Katayoun (2016) 'Anti-Muslim assaults reach 9/11-era levels, FBI data show.' PewResearchCenter, November 21, http://www.pewresearch.org/fact-tank/2016/11/21/anti-muslim-assaultsreach-911-era-levels-fbi-data-show/. Accessed on April 26, 2017.

Kaplan, E. Ann (2005) Trauma Culture: The Politics of Terror and Loss in Media and Literature. New Brunswick: Rutgers University Press.

Knapp, Kathy (2014) American Unexceptionalism: The Everyman and the Suburban Novel after 9/11. Iowa City: University of Iowa Press.

McInerney, Jay (2007) The Good Life (2006). New York: Vintage.

Messud, Claire (2007) The Emperor's Children (2006). New York: Vintage.

Mishra, Pankaj (2007) 'The End of Innocence.' The Guardian, May 19, https://www.theguardian. com/books/2007/may/19/fiction.martinamis. Accessed on July 19, 2017.

Morey, Peter and Amina Yaqin (2011) Framing Muslims: Stereotyping and Representation after 9/11. Cambridge: Harvard University Press.

Peek, Lori (2011) Behind the Backlash: Muslim Americans after 9/11. Philadelphia: Temple University Press.

Petrovic, Paul (2015) 'Introduction: Emergent Trends in Post-9/11 Literature and Criticism.'In: Petrovic, Paul (ed.) Representing 9/11: Trauma, Ideology, and Nationalism in Literature, Film, and Television. Lanham: Rowman \& Littlefield, ix-xvii. 
PewResearchCenter (2014) 'Is the Islamic Religion More Likely than Others to Encourage Violence?' Growing Concern about Rise of Islamic Extremism at Home and Abroad, September 10, www.people-press.org/2014/09/10/growing-concern-about-rise-of-islamic-extremism-at-homeand-abroad/9-10-2014_9/. Accessed on April 26, 2017.

PewResearchCenter (2011) 'Challenges, Worries, and Concerns.' Muslim Americans: No Signs of Growth in Alienation or Support for Extremism, August 30, http://www.people-press. org/2011/08/30/section-4-challenges-worries-and-concerns/. Accessed on July 25, 2017.

Pöhlmann, Sascha (2010) 'Collapsing Identities: The Representation and Imagination of the Terrorist in Falling Man'. In: Schneck, Peter and Philipp Schweighauser (eds.) Terrorism, Media, and the Ethics of Fiction: Transatlantic Perspectives on Don DeLillo. New York \& London: Continuum, 51-64.

Randall, Martin (2011) 9/11 and the Literature of Terror. Edinburgh: University Press.

Simpson, David (2008) 'Telling It Like It Isn't'. In: Keniston, Ann and Jeanne Follansbee Quinn (eds.) Literature after 9/11. New York: Routledge, 209-223.

Sklar, Howard (2013) The Art of Sympathy in Fiction: Forms of Ethical and Emotional Persuasion. Amsterdam: John Benjamins.

Sykes, Rachel (2014) 'A Failure of Imagination? Problems in 'Post-9/11' Fiction.' In: Fanuzzi, Rober and Michael Wolfe (eds.) Recovering 9/11 in New York. Newcastle upon Tyne: Cambridge Scholars 248-262.

Updike, John (2007) Terrorist (2006). London: Penguin Books.

Vanderwees, Christopher (2014) 'A Tightrope at the Twin Towers: Photographs of Falling Bodies and James Marsh's Man on Wire'. In: Fanuzzi, Rober and Michael Wolfe (eds.) Recovering 9/11 in New York. Newcastle upon Tyne: Cambridge Scholars, 228-247.

Versluys, Kristiaan (2009) Out of the Blue: September 11 and the Novel. New York: Columbia University Press.

Waldman, Amy (2012) The Submission (2011). London: Windmill Books.

Sini EIKONSALO is a PhD student in English literature at the University of Edinburgh. She is writing her dissertation on the representation of Islam and the United States in American 9/11 novels. She graduated from the Master's program in narrative theory and textuality at the University of Tampere in Finland. She has also spent time studying as an exchange student and working as research assistant at Masaryk University's Department of English and American Studies in Brno, Czech Republic.

Address: MA Sini Eikonsalo, Department of English Literature, School of Literatures, Languages and Cultures, University of Edinburgh, 50 George Square, Edinburgh EH8 9LH, United Kingdom. [email: s1787074@sms.ed.ac.uk] 